European journal of American studies

Special Issue: Re-Queering The Nation: America's

Queer Crisis

\title{
Un-quaring San Francisco in Milk and Test
}

Clayton Dillard

\section{(2) OpenEdition}

Journals

Electronic version

URL: https://journals.openedition.org/ejas/11714

DOI: 10.4000/ejas. 11714

ISSN: 1991-9336

Publisher

European Association for American Studies

\section{Electronic reference}

Clayton Dillard, "Un-quaring San Francisco in Milk and Test", European journal of American studies

[Online], 11-3 | 2017, document 3, Online since 24 January 2017, connection on 08 July 2021. URL:

http://journals.openedition.org/ejas/11714 ; DOl: https://doi.org/10.4000/ejas.11714

This text was automatically generated on 8 July 2021.

Creative Commons License 


\title{
Un-quaring San Francisco in Milk and Test
}

\author{
Clayton Dillard
}

1 Around the midway point in Milk (Gus Van Sant, 2008), San Francisco politician Harvey Milk (Sean Penn) sits in his office eating lunch with several of his campaign volunteers, including Cleve Jones (Emile Hirsch), a young, curly-haired white male originally from Phoenix. Strategizing about ways to defeat the 1978 Briggs Initiative, which would ban gay teachers and any of their supporters from teaching in California public schools, Harvey says: "We need something populist... What's the number one problem in the city?" Cleve responds, "The fucking piss smell in the Tenderloin." Harvey says, "Close," but ultimately settles on cleaning up the city's "dog shit" as the wiser crossover issue. Cleve's negative opinion of the Tenderloin district finds corroboration in a 1977 article from the New York Times, where the district is described as a "desolate Pigalle," and an enclave for "freaks, welfare cripples, runaways, and drug hustlers" (Gold 17). Overlooked and unremarked upon throughout Milk, however, is the Tenderloin's preeminent history as a site for queer life during the 1960s, one that precedes the "Great Gay Migration" of the 1970s and 1980s into San Francisco's Castro District (Howe 38). A 1966 study of the Tenderloin conducted by the Council on Religion and the Homosexual found that "homosexual behavior" was prominent among young men and that many of the district's women were not only prostitutes, but also lesbians (Sides 98).

Aecordingly, this scene, in its correlation of the Tenderloin with urine, suggests the Castro has a monolithic claim on San Francisco's queer community at the expense of all (historically relevant) others. The Castro is understood as a mythic destination, amplified by screenwriter Dustin Lance Black's narrational structure, which uses Harvey's recorded will as a voiceover track to supplement archival and dramatic footage. As Harvey and Scott (James Franco), his partner, arrive in the city, Harvey explains the historical moment circa 1972: "In those days, San Francisco was the place where everyone wanted to go... To drop out... To fall in love... But by 1972, The Haight was boarded up. Crime-filled. Drug-filled. The new place for us refugees was 
this run down Irish Catholic neighborhood in Eureka Valley. Six blocks square... The Castro." While this brief narrative of queer history in early 1970s San Francisco correctly identifies the Castro as a primary destination for queer "refugees," the lack of context for other emergent queer neighborhoods reduces queer geographic history within the city to a singular setting. In fact, by the early to mid-70s, continued legal reform and tolerance from SFPD for gays in public places allowed the blossoming of "four geographically distinct gay male neighborhoods" across San Francisco, including the Mission District, Polk District, South of Market District, and the Tenderloin (Sides 102).

Moreover, without mention of ethnicity, class, or gender, Harvey's assessment presumes "us refugees" as an equal-opportunity grouping of singular queer identity that marginalizes the actual experience of difference within the Castro during the time period. ${ }^{2}$ The tendency to omit divisions within the gay community may be a facet of the film's historical whitewashing, but it is also a historically characteristic trend of discourses about queerness produced by gay white men. As J. Todd Ormsbee explains, while San Francisco's ethnic diversity in the 1960s became one of the city's defining traits, it is also the very trait that presented "the most troublesome problems for gay community building," primarily because, despite gay liberation's identification with various civil rights groups such as the Black Panthers, gay men "produced a discourse of community in their [newspaper] publications that belied an assumed whiteness of their community" (148; original italics). By focusing exclusively on a singular definition of queer experience, these writings both ignored non-white vantage points and shrunk San Francisco's geography to the Castro, where gay lives were most visible or, rather, most visible to one segment of the gay community.

Milk stages confrontations between gay tolerance and homophobia but minimizes racial difference, with Harvey's passing reference to his own Jewishness while being confronted by a liquor-store owner one of the film's only acknowledgements of ethnic specificity. Given the marginality of persons of color throughout, Milk adheres to, and perpetuates, a history of limited scope that makes homosexuality synonymous with white men. ${ }^{3}$ Moreover, the film constructs a definition of gay life that resembles dominant narratives of nationalism, where class and race comingle as an essential determiner of difference. These representations are contrary to the idea of aqueer homeland, which is explained by Alyssa Howe as a place that offers "a symbolic refuge for believers who make the pilgrimage," which seeks to validate the acceptance of differences between people since "a homogenous, one dimensional sense of queer identity does not appear to serve the purposes of an inclusive homeland" (36-40). Howe's understanding of a queer homeland relates to E. Patrick Johnson's conception of "quare studies," a vernacular form of queer studies that is capable not just of "speaking across" identities, but also articulating them (3). Quare studies emphasizes lived experience and the local, thus encompassing ethnicity, class, and gender. Johnson sees quare studies as "an epistemology rooted in the body," one that rejects any form of "monolithic identity" and "narrow cultural nationalism" in favor of theorizing how the discursive mediation of subjectivity and agency "may propel material bodies into action" (9). It is my contention that Milk not only eliminates bodies of color from its queer perspective, but engages in what I am calling an unquaring of San Francisco's population diversity. 
Ins this essay, I examine San Francisco's historically diverse queer districts in relation to the homonormativity offered in Milk as a means of reclaiming the city as a quare space. In this, I follow Rosalyn Deutsche's method of "urban-aesthetic discourse," which studies spatial politics through omissions and concealments of difference (xii). Deutsche reconfigures discourses surrounding modernity by pointing out how numerous theorists have ignored questions of difference in defining the material terms of modernity. Deutsche makes this claim from a primarily feminist perspective and states that "a synthesis of urban and cultural disciplines has... constructed a coherent field by eliminating feminist criticism" (198). Deutsche's revised spatial politics understands the material particulars of any city through an emphasis on conflict and refutes spatial narratives that justify exclusion with falsified claims of harmony. Accordingly, I explain how Milk conceals difference through its spatial depiction of an emerging gay civil rights, where not only "gay" but also a coherent social space came to be synonymous with whiteness. I have chosen the term "un-quaring"rather than "dequaring" to emphasize that San Francisco has never been quare, if measured by its official discourses. The film erases from its historical record the transgender population in the Tenderloin and the gay Latino population of the Mission District so that the Castro becomes a monolithic emblem of all queer history in San Francisco. The following two sections of this essay provide historical context and a close reading of Milk to demonstrate how this relationship works. In a third section, I turn my focus to Test (Chris Mason Johnson, 2013), an independent American film set in 1985 San Francisco during the onset of the AIDS crisis. Test treats the city in similar ways as Milk by filtering the crisis through the eyes of gay white men and reduces the city to a series of geographical markers rather than a vibrant queer place filled with diverse peoples. While it is perhaps unsurprising that Milk, a prestige Hollywood film, would engage normative depictions of queerness and whiteness, my point in juxtaposing the two films is to demonstrate how pernicious this discourse is and that it persists no matter the industrial formation.

\section{Milk and a Brief History of Queer San Francisco}

Røleased in North America in November of 2008, Milk garnered positive reviews from critics and was named the best film of the year by both the New York Film Critics Circle and the San Francisco Film Critics Circle. However, there were a few dissenting reviews that noted some of the film's flaws. New Republic bemoaned the film's "belatedness" and its choice to "shamelessly rip off" the 1984 documentary, The Times of Harvey Milk (Orr). Walter Chaw deemed the film "Ray set in the Castro," believing that Black's script followed the biopic model "in almost every traditional, conventional sense" (Film Freak Central). And the Daily Mail saw the film as a sanitized account of Milk's biography, failing to recognize both his former years as a stockbroker and his income from "processing hard-core gay pornography in his photographic store" (Tookey). Only one critic-Armond White-recognized the film's reliance upon Harvey Milk as a "white idol" for the gay movement. White claims the choice is a "mainstreaming ploy" that marks it as "this year's official gay martyr movie" (White). Subsequent essays written well after the film's initial release critiqued Milk'sracial exclusion, noting how the film "depicts something that looks more like gay rights politics today" (Spade and Willse 72) and "canonizes a certain white gay male history as 
the story of queer liberation" (Lenon 48; original italics). These accounts broach alternative queer histories, though only in passing, if at all. ${ }^{4}$ Accordingly, this section identifies gaps within Milk's monolithic account of San Francisco by drawing upon historical data that affirms both an active queer culture-and queer activism-in several other districts of the city.

Evaluating queer life in San Francisco along ethnic lines is an imperative for diversifying the city's urban-aesthetic discourse. Such an effort also intersects with the city's immigrant history during the 1960s and beyond. The liberalization of immigration policy in 1965 led to a dramatic increase of immigrants-specifically, Chinese-moving into San Francisco and California as a whole (De Graauw 31). In fact, following the 1965 Hart-Cellar Act, which removed restrictions on non-European migration, San Francisco saw "large numbers of immigrants from Asian and Latin America," which changed the "ethnoracial composition of San Francisco's population in dramatic ways" (De Graauw 59). Though data on self-identified sexual orientation among these immigrants is scant, this influx can nevertheless give us a framework for understanding the situation of the "sexile." Manual Guzmán coins the term to describe individuals "who have had to leave their nations of origin on account of their sexual orientation," but Horacio N. Roque Ramírez expands it to include "not only those who left their nation but also those who left their home state, region, or family base for another place in their own country" (Ramírez 225). Thus adapted, sexile applies to several characters in Milk;Harvey and Scott move to San Francisco from New York, and Cleve moves to the city from Phoenix. Harvey even advocates sexilism as a progressive practice. While awaiting a phone call from Scott, Harvey receives a call from a boy in Minnesota claiming he wants to kill himself because his parents are taking him to a hospital to be "fixed" in the morning. Concerned, Harvey offers the following advice: "Get on a bus. Go to the next biggest city. New York, San Francisco, L.A., or even Minneapolis. It doesn't matter. Just leave. You won't be alone. There are people out here just like you who will welcome you and love you. You're not sick. You're not wrong. God does not hate you. Just leave." In this manner, the sexile becomes a general marker of resistance and non-specific to a particular place and time. The sense that all "big cities" are the same ignores ethnic difference while perpetuating a rhetoric of inclusion that is unsubstantiated. In other words, as spoken by Harvey in this scene, becoming a sexile is not only easy, but promises utopian ends.

Harvey's rhetoric also implies a binaristic opposition between city spaces and rural locations, effectively pinning the United States's discrimination against queer lifestyles on a conservative mindset more likely to be found in the backwoods than the modern, urban city. While Harvey expresses an awareness of the discrimination faced by gays within San Francisco, the assumption is that the city is superior, even though Milk makes no attempt to examine where earlier forms of struggle and resistance arose within the city. The documentary Screaming Queens: The Riot at Compton's Cafeteria (Victor Silverman and Susan Stryker, 2005) examines a 1966 riot in the Tenderloin district, where numerous transgender women and drag queens confronted an instance of police brutality. The incident, and many like it, offers an example of queer resistance in San Francisco that takes place outside of the Castro. As the opening voiceover to the documentary states: "What really happened that night at Compton's Cafeteria has been all but forgotten." Through interviews with several transgender women of various ethnicities, the documentary recovers the event through testimonials and archival 
documents. In fact, director Susan Stryker, herself a transgender woman, first learned of the riot while conducting research at the Gay and Lesbian Historical Society. The documentary opens with footage taken from a 1960s training video made by the San Francisco Police Department that claims the Tenderloin to be "the home ground of the always visible segment of the city's homosexuals and transvestites," and is composed with noirish saxophone music and slow-motion imagery that likens queer activity to vampirism, explaining how homosexuals "reveal their true colors at night." The video's fear-mongering rhetoric and portentous style confirm that cities are also contentious sites for homosexuals.

The point is not that Milk should be expected to address the specific circumstances of the Tenderloin during the 1960s, but that the film neglects to integrate any events or alliances outside of the Castro, or of peoples of color, into its queer geography. Not only does Milk lack both transgender visibility and San Francisco's most commonly transgender spaces, it also deploys ethnicity as a punchline rather than an integral component of the city's identity during the late '70s. One of Harvey's boyfriends, Jack Lira (Diego Luna), is Latino, though the film only acknowledges as much in pejorative ways. Harvey refers to him affectionately at a party as "taco," to which Scott says: "Don't let Cesar Chavez hear you calling him taco." That the exchange takes place out of Jack's earshot suggests that Scott remains Harvey's more suitable partner because they share whiteness and can joke about Jack behind his back. ${ }^{5}$ The other recognition of Jack's ethnicity comes from Dan White (Josh Brolin), who drunkenly refers to him as "Latino man" while confronting Harvey. This minimizes both Jack's queerness and ethnicity, and the representation is especially vexing because the Gay Latino Alliance (GALA), made up of populations in San Francisco's Mission and South of Market districts, formed in 1976-a year before Harvey Milk's assassination. GALA formed, in part, as a response to the overwhelming whiteness of the Castro; as Rodrigo, a gay Latino male, explains: "The Castro was growing by leaps and bounds, and I was very much involved in that scene. At that time the bars were dominated by white folks, and there was no place for Latinos really to come together" (Ramírez 232). The group primarily formed in order to give a voice to the socio-political interests of gay Latinos, but concerns were not restricted to messages within the gay community; instead, the group sought to speak to the Latino community as a whole, housed primarily within the Mission district, in order to achieve a cultural awareness for both an emergent ethnic and sexual identity. Accordingly, "GALA did not divorce its sexual politics from its cultural roots or its critique of white gay racism from its challenge to Latino homophobia" (Ramírez 258). Milk uses its sole Latino character for stereotyping and overlooks an imperative, gay Latino movement happening in the city concurrently with its own narrative.

These issues are exacerbated through a further un-quaring of San Francisco at the level of sexual intercourse, where the only sex presented on screen mirrors that of prestige Hollywood films featuring heterosexual characters, so that kissing, cuddling, and pillow talk comprise the bulk of these sparse scenes: one taking place between Harvey and Scott, the other between Harvey and Jack. Even the Castro is stripped of its sexual specificity, let alone other districts like South of Market, where leather clubs like the Catacombs, which opened in 1975, were known for fisting. The district was no mere blip on the radar either; in fact, "by the late 1970s, South of Market (also known as Folsom) had become one of the most extensively and densely occupied leather neighborhoods in the world" (Rubin 107). Milk promotes homonormativity as Lisa 
Duggan defines it: "there is no vision of a collective, democratic public culture or of an ongoing engagement with contentious, cantankerous queer politics" (189). Including districts populated by transgender, Latino, and leather members of the queer community would not be cantankerous by definition, but acknowledging the politics, let alone presence, of these communities would gesture away from homonormativity and toward transforming San Francisco into an inclusive queer homeland. Furthermore, the reliance upon a predominately white, non-threatening, and sexually passive contingent of the Castro district to embody queer experience demonstrates how places like South of Market offer an image of queerness that remains incompatible with dominant political life. There is historical precedent for this, since "the Castro was unquestionably the center of local gay politics, but the Folsom had become the sexual center" (Rubin 107). Yet homonormativity entails just this: a separation of the political and sexual from one another in order to privilege a form of queer identity that most closely resembles heteronormativity. Milk speaks to this directly as both aesthetic artifact and historical document. Harvey's attempt to minimize a hostile or "cantankerous" queer politics throughout the film finds a parallel in Van Sant and Black's homogenized representation of San Francisco's queer complexity.

\section{Milk and the Politics of Quare Space}

Black's screenplay focuses on Harvey Milk's emphasis on gay rights through the phrase "I'm Harvey Milk, and I'm here to recruit you," repeated throughout the film as Harvey's slogan for political mobilization. However, the screenplay minimizes scenes of Harvey's speeches (aside from a lengthy one given while under threat of assassination), to the extent that only sound bites of Harvey's politics emerge. Instead of showing Harvey working in and interacting with other communities, the film reduces his politics to refuting "all the bigots out there," like John Briggs and Anita Bryant, whose support of Proposition 6 in 1978 becomes the film's central focus. In this speech, bigotry refers to the politicians' homophobia, and Harvey's reference to Emma Lazarus's poem "The New Colossus," with the line "give me your tired, your poor, your huddled masses yearning to be free," further suggests bigotry as an exclusive conflict between gay acceptance and homophobia. In fact, nowhere in Black's screenplay does race factor into Harvey's politics, even though, in his actual political life, Harvey Milk was an adamant advocate for agreement and cooperation between communities of differing ethnicities. ${ }^{6}$ In this section, I will consider how the Castro itself is neutralized as an actively queer space and made, instead, into a space that incidentally houses queer peoples.

Milk's investment in Harvey's romances is epitomized by a slow motion, highangle shot from outside of Castro Camera, Harvey's camera store. There, Harvey and Scott kiss while the camera zooms out, revealing a wider stretch of Castro Street. The mise-en-scène introduces surroundings that are shut out of the couple's insular make out, suggesting a liberatory act for the gay couple, whose intimacy has finally found a home. This sort of contrived, universalized depiction of queer life occurs throughout Milk, which pushes historical specificity to the periphery and centers on an infatuation with gay coupling. As presented in the film, Castro Camera is no more than a means for Harvey and Scott to scrape by on meager earnings. The establishment is also the locus for Harvey's initial campaign activities, and it's where he becomes committed to a form 
of politics that emphasizes the emergence of gay activism (depicted here as predominately white, male, and middle-class). It's also telling that other staple locations within the Castro, such as gay bars and clubs, are only glimpsed in reference to Harvey's boycott of Coors Beer, whose anti-union policies have led to a significant workers strike. These locations receive meaning because of Harvey and prove incidental to the film's interest in queer narratives. Accordingly, the bars' complicated social histories are diminished, since quare men and women of differing ethnicities dealt with alienation and discrimination from these very spaces. ${ }^{7}$ Hence, the Castro's social history is collapsed into Harvey's political interests in appealing to a particular voting bloc.

When quare people or places appear in Milk, they do so as an unexamined emblem of tokenism. While Harvey works inside his camera store in preparation for an upcoming election, a gay male couple walks by the store window. One of them-a black man-says: "Gonna win this time, Milk?" In another instance, Harvey is glimpsed inside of a barbershop with black owners during a campaign montage, though it's not clear in which part of the city this scene is meant to be set. Perhaps the most notable example of quare visibility is a celebration scene set inside of City Hall, where Sylvester, a famous Bay-Area drag queen, performs the song, "You Make Me Feel (Mighty Real)." However, no one addresses the singer by name, rendering Sylvester's presence an unacknowledged backdrop to the festivities. Such an inclusion actually masks a harsher reality of alienation for members of the queer community who did not conform to the "insular and homogenous" tenor the district started to attain in 1977, where "the counterculture types-the arts queens, the radical faeries, and the political queens... found themselves edged out" (Gamson 129). The emergent figure of the Castro at this time became known as the "Castro Clone," which offered "a vision of sameness, of short-haired white men and no beads at all, of a gay culture that was not strange" (Gamson 130). Sylvester's integration epitomizes Milk's un-quared San Francisco, where queer difference is ignored in favor of an opportunistic melting of historical specificity, so that one queer signifier is merely interchangeable with another and necessitates no attention as a multi-dimensional component of represented space.

Milk maintains a vision of San Francisco in the 70s dominated by white middleclass gay men, even though there are many minority-group narratives that refute such a homogenous understanding of the city's history. However, the problem existed in the 70 s as well; as Christina Handhart explains in an article on the city's Butterfly Brigade, which helped create what became known as a "safe space" throughout the Castro and was patrolled by volunteers armed with whistles, the term actually applied almost exclusively to gay white men. That is due, in part, to the fact that "the majority of the patrollers themselves were white men" and that key patrolling areas often bordered neighborhoods that were "home to large numbers of low-income people and people of color" (Hanhardt 66-70). Hanhardt explains that these practices could be understood as assisting in "patterns of neighborhood gentrification and segregation," and that "gay people were being used by speculators to 'bust' neighborhoods by moving white gays in and families of color out" (Hanhardt 70). Hanhardt convincingly addresses the city's spatial politics, so that a film like Milk demonstrates a continuing legacy of exclusionary practices that were established contemporaneously with the activism depicted in the film. Moreover, Milk closets a prior, hidden history of San Francisco as a place of quare oppression through its whitewashing of both the Castro and the city as a whole, because quare discourse finds no purchase within the filmmakers' sense of Harvey's 
significance. Hanhardt singles out the Tenderloin as a district that provided no protection for queer people in the late 70 s, due to "the extent of middle-class reinvestment in central cities and concomitant growth of professionals in the urban service sector, both phenomena that included gay men" (74). Milk appears to have an interest in guarding "a specific kind of gay identity that reflected the race and class stratification of the city itself" (Handhart 75; original italics). A city's complex history and all of its spatial prejudices, then, is erased when rendered by those who previously, as now, provide a dominant perspective that neglects to account for queer diversity.

\section{Test and the Politics of Quare Space}

Milk is an entry into a form of Hollywood cinema that came about in the mid-1990s when the "gay consumer" became a viable market demographic, beginning with the release of Philadelphia (Jonathan Demme, 1993) from TriStar Pictures, and continuing into the twenty-first century with Brokeback Mountain (Ang Lee, 2005) and Dallas Buyers Club (Jean-Marc Vallée, 2013), both released by Focus Features, a subsidiary of Universal. ${ }^{9}$ There are other films that could be mentioned here, but these three, like Milk, are also notable for having their lead performer-all playing gay white men-be nominated for an Academy Award for Best Actor. ${ }^{10}$ These films also address themselves to "a straight, mainstream audience, evident through [their] narrative, the representation of the main gay character and the casting of avowedly straight Hollywood stars" (Mennel 95). I would add to these characterizations an emphasis on the decided whiteness of being gay as represented in these films, particularly because there is not a single example, in Hollywood history, of a comparable prestige film made about a queer person of color. Therefore, not only are these stars avowedly straightthey are also avowedly white and occupy spaces where people of color are largely absent. $^{11}$

Outside of Hollywood, the space of politics in post-millennial queer cinema has typically been understood through "an embrace of the real," as Ben Walters calls it in a 2012 article for The Guardian. These new films deal in "real life and rounded characters... to tell a story rooted in psychological specificity, but with universal romance" (Walters). Walters mentions films like Weekend (Andrew Haigh, 2011), Keep the Lights On (Ira Sachs, 2012), and I Want Your Love (Travis Matthews, 2012), and pinpoints aspects that each of these filmmakers highlight in their work, such as a desire for connection that transcends "being gay," and "embracing sexual behaviour as it is." While both Walters and the directors explain an interest in telling progressive stories about queer peoples, neither party mentions ethnicity or politics of any kind. In the three films discussed, political and ethnic matters are omitted for a focus on coupling itself, the angst of being a wayward twentysomething, and an intensive interest in the personal lives of its characters. Haigh sums up the approach at the end of the article, saying: "We're not afraid to tell stories about flawed gay individuals who are fully rounded characters and just as fucked up about life as everyone else." Although Walters doesn't mention Milk in his overview, the film's interest in detailing Harvey's personal life over his political outlook gives it comparable traits. Black has emphasized as much, explaining how he wanted to offer an "honest" portrait of Milk that depicts him as "a real character... he was extremely influential as an activist and politician, but as a businessman and in his personal life he was a spectacular failure" 
(Vice). In other words, Black's interest in a particular form of rounded characterization comes at the expense of both an ethnic or spatial politics. In the case of Milk, Harvey's personal life unites with his politics through lobbying for increased gay civil rights, but the film perches Harvey's romantic affairs above his political dealings and community interests. As Black further explains, "The thing I wanted to do in the script was to get much more personal. [The Times of Harvey Milk] doesn't have most of the stories that I was drawn to" (Cline).

Accordingly, it is clear that this next wave of queer cinema largely relies upon narratives that revolve around the coupling of gay white men. The films, like Milk, ignore the spatial politics either endemic to or surrounding that coupling. Importantly, all of the films mentioned in Walters's article are set in the present and lack a historical dimension that necessitates an attentiveness to spatial politics or the recreation of a time period. That's not the case for Test, an American indie drama set in 1985 San Francisco during the beginnings of the AIDS epidemic. An HIV test has just been made available, which concerns Frankie (Scott Marlowe), a gay white twentysomething dancer in a ballet company, who is frightened that he may contract the virus. Frankie lives in the Upper Castro and often peers from his window, with the Sutro Tower several miles in the distance. Test uses the tower as its recurring landmark, with Frankie walking through Buena Vista Park every morning on his way to the studio, where he's an understudy for an upcoming show. The geography is never mentioned or demarcated by subtitles, but the tower and repeated shots of Victorian-style houses in the Castro make the locations unmistakable-a visual shorthand that may speak to the film's low budget of only $\$ 130,000$. Nevertheless, Test works to disguise its historical specificity despite sporadic reminders of it, such as a newspaper headline from The Guardian reading "Should Gays Be Quarantined?" Accordingly, there is little interest throughout Test in exploring its characters' socio-economic lives, their ethnicity (nearly every character is white), and the looming AIDS epidemic, which presents its threat mostly through radio reports on the deteriorating health of actor Rock Hudson. These broadcasts pervade the film as a recurring means of establishing the historical time and place.

Test reduces San Francisco to a backdrop for allowing a smaller drama to unfold that could just as easily have been set in the present. In fact, director Chris Mason Johnson has referenced the films mentioned in Walters's article as contemporaries for Test, with the lot of them suggesting that "we're starting to see a different kind of realism again" (Lattanzio). Once more, the notion of realism is that which occurs at a character level, where things like moments from a sex scene or prolonged conversations between characters stand in opposition to more montageoriented, sanitized Hollywood filmmaking. However, on the level of geography, these filmmaking efforts carry an identical, fundamental effect in how they take no reflexive interest in addressing spatial politics, so that "realism" as it's being practiced both here and in Milk becomes a hollowed signifier that caters to a homonormative restructuring of queer lives. Test employs realism as a de-politicizing act by separating private intimacy from a form of public expression. The Castro is never mentioned throughout the film except as a source of derision. During an early party, one character remarks that another "won't eat in the Castro anymore. She thinks it's like hepatitis in the food." At another point, a cab driver remarks to Frankie: "What do you want to come down here for? It's nothing but a bunch of human garbage." These homophobic remarks are incidentally validated by the film's refusal to cast the verbally derided 
spaces as actual, seen-and-lived places for interactions amongst members of the queer community. A scene set inside a Castro bar quickly ends as Frankie meets Walt (Kristoffer Cusick) and the two end up having unprotected sex at Walt's place. Later in the film, when it's discovered that Walt is HIV-positive, the film rhetorically validates the prior homophobia by confirming its characters' fears of places and their homophobic connotations.

Moreover, since AIDS appears throughout the film more as a scare tactic to motivate character relationships than inform a portrait of 1985 San Francisco, Test participates in a similar fear of actual spaces that was common throughout the city in the mid-80s. For example, Gayle S. Rubin explains how a significant blame for AIDS was directed against "subgroups within the gay community," among them drag queens and, most particularly, the "sleazy South of Market leathermen," as voiced in a 1982 letter to the editor for the Bay Area Reporter (Rubin 111-12). ${ }^{12}$ The explicit invocation of the Castro as the sole site of the AIDS crisis also excludes how several other districts, like the Tenderloin, were experiencing similarly epidemic levels of infection, both from sex and intravenous drug use. In fact, 1985 was perhaps the imperative year during the emergent months of the epidemic, as groups like COYOTE (Call off Your old Tired Ethics) strove to provide preventative measures for prostitutes in the Tenderloin, for whom HIV had become prevalent (Sides 183). While hospices and other kinds of care became common throughout the Castro, these services were virtually nonexistent in the Tenderloin "because of the profoundly impoverished and highly transitory population there" (Sides 185). These historical details are matters of class and ethnicity as they relate to place and, in their specifics, could constitute a form of textual realism that aligns with the aforementioned approach of GALA, which did not "divorce its sexual politics from its cultural roots or its critique of white gay racism" (Ramírez 258). On the contrary, Test, like Milk, routes its social realism into the interior lives of white male members of the queer community.

That problem, also as in Milk, revolves around scenes that feature facets of queer culture beyond its white male contingent, but only as a background or incidental presence. While Frankie visits the apartment of a white neighbor, Sylvester's song "You Make Me Feel (Mighty Real)" plays on the man's stereo-the identical song played during the City Hall celebration scene in Milk. The music choice lends the interior apartment space an exterior queer presence by affiliation only and does so in a manner that goes unremarked upon by either man. The music track, like the Sutro Tower, fulfills a general marker of a possible queer space that can be sampled and used as a stand-in for a more specific usage of queer cultures. To be gay in Test means to exist in a space that's fortified through stereotypical signifiers, where shots of San Francisco, writ large, are meant as shorthand for a gay lifestyle. Both Milk and Test treat the city in this manner, calling upon Sylvester's likeness and music to configure the space into a recognizable moment from the past.

Both films write this discourse onto the city's districts through a focus on the Castro and an absence of others, but in Test, resistance to AIDS is indirectly found through the homonormative maintenance of the gay white male body as a form of selfdiscipline. The film's central focus on a dance company allows for numerous performance sequences, but its inclusion also draws attention to an idea of masculinity affiliated with strength, posture, and sculpted bodies. While performing a few moves during practice, Frankie is berated by his instructor to "dance like a fucking man... 
think about what that might mean physically, in your hands and feet." The scene follows a previous exchange where Frankie is told by Todd (Matthew Risch) that he "looks like a little boy" in reference to seeing him naked in a locker room. While the film resists these comments by empowering Frankie to take control of his body and eventually perform the moves his own way, the indirect consequence of these developments validates the notion that to be strong-to have the capacity for physical dexterity-is to resist the temptations of a homosexual lifestyle that the film directly affiliates with AIDS. Test allows Frankie to maintain a gay identity, but only so long as he resists cruising and maintains a personal, physical awareness. Frankie's sole cruising venture results in having unprotected sex with Walt. During their second encounter, when Frankie suggests they use contraception, Walt scoffs at the notion. Subsequently, when Walt discovers he's HIV-positive, the film affirms Frankie's commitment to bodily protection and reformation. Those precautions stand in direct contrast to Todd, whose admission that he sells his body for sex prompts Frankie's words of warning that he could "get something." However, Frankie does not advocate contraception or care while tricking, but abstinence from the practice altogether. Put another way, AIDS becomes something that "those men" get-those unwilling to protect their bodies and maintain them through proactive solutions and methods of bodily care.

The body, then, stands in for a homonormative spatializing of San Francisco, where an emphasis on athleticism, as a distinctly masculine trait, helps to cultivate the gay white male body into a desirable form for the community as a whole. Nevermind that the entire company, aside from an Asian female character that does not have a speaking role, is composed of white dancers; it is the lack of recognition of whiteness or potential diversity within the company beyond gay identity that presumes as much. That is, without questioning a queer identity beyond Frankie's immediate purview, Test rests upon the presumption that Frankie's experience speaks for the entire city's queer population. At the end of the film, as he concludes that monogamy is "like a test," the film's rhetorical gesture aligns fidelity and his own HIV-negative body, implying that one practice yields another. In this final gesture, Test refutes any such "cantankerous queer politics" in favor of a conservative party line that effectively castigates sexual practice outside of monogamy and exclusively advocates protected sex with one partner. The issue is not the message as such, but that the film's sense of historical relativism entails a solution to both the AIDS crisis and personal relationships that is irrespectively offered with regard to socio-political and economic status. The Castro is meant for the "Castro clone," and other districts that house queer people are to be either ignored entirely or derided for their affiliation with a bodily stench.

\section{Conclusion}

American cinema lacks a diversity of voices to account for the complexities of queer lives beyond those of gay white men, who typically remain confined to examining the lives of gay men who share their own socio-economic and ethnic background. A director such as Gregg Araki addresses a more inclusive queer space in his films, but they are an anomaly within the greater, queer-film canon. Medicine for Melancholy (Barry Jenkins, 2008) is not a film about queer lives, but it does offer an instructive example of how San Francisco's history is marked by discourses that belie the city's assumed whiteness.As an African-American couple walks throughout the city, 
they visit the Museum of the African Diaspora located in the South of Market District and attend an affordable housing coalition meeting. In doing so, they discuss the city's racial history and the contemporary effects of gentrification. Their conversations and movements demonstrate how spaces become places through an investment of both personal and collective meanings by those who inhabit them. The film acknowledges that, in San Francisco during the 70s and 80s, many neighborhoods, districts, and people of differing ethnicities and sexual identities worked to formulate environments that were capable of giving a voice to their daily, personal struggles. That the film was released the same year as Milk but received far less critical interest, industry recognition, or public attention demonstrates how prevalent, and commercially appealing, a homonormative presentation of city life has become.

Imsum, the emergence of a cohesive contingent of gay activism in the Castro, while important to giving the movement a public face in politician Harvey Milk, brought with it the beginnings of a legacy of exclusionary representational practices that privilege the perspective of gay white males as the defining voice and image of a much larger, and ethnically diverse, queer community. Milk and Test, which are both structured around images of powerful gay white male bodies, perpetuate this lineage by erecting a monolithic identity of gayness and sustaining a narrow cultural nationalism for San Francisco as a whole. The cumulative effect is an un-quaring of the city that continues to minimize ethnicity and district-specific socialization within queer historiography.

\section{BIBLIOGRAPHY}

Armstrong, Elizabeth A. Forging Gay Identities: Organizing Sexuality in San Francisco, 1950-1994. Chicago: Chicago UP, 2002. Print.

Betsky, Aaron. Queer Space: Architecture and Same-Sex Desire. New York: William Morrow and Company, 1997. Print.

Black, Dustin Lance. Milk: The Shooting Script. New York: New Market P, 2008. Print.

Black, Jason Edward and Charles E. Morris III, Eds. An Archive of Hope: Harvey Milk's Speeches and Writings. Berkeley: U of California P, 2013. Print.

Boyd, Dick. "Before the Castro: North Beach a gay mecca." The Semaphore 189 (2010): 16-23. Web. 25 May, 2016.

Boyd, Nan Alamilla. Wide-Open Town: A History of Queer San Francisco to 1965. Berkeley: U of California P, 2005. Print.

Chaw, Walter. “Che (2008) + Milk (2008)." Film Freak Central (Jan 2009). Web. 25 May, 2016.

Cline, Rich. "RT Interview: Gus Van Sant and Dustin Lance Black on Milk." Rotten Tomatoes (Jan 2009). Web. 25 May, 2016.

Cook, Matt. and Jennifer Evans, Eds. Queer Cities, Queer Cultures: Europe since 1945. London: Bloomsbury, 2014. Print. 
Croce, Fernando C. “(Un)Happy Cows: Milk, Australia, Quantum of Solace, Twilight," CinePassion (Dec 2008). Web. 25 May, 2016.

Deutsche, Rosalyn. Evictions: Art and Spatial Politics. Cambridge: The MIT P, 1996. Print

Duggan, Lisa. "The New Homonormativity: The Sexual Politics of Neoliberalism." Materializing Democracy: Toward a Revitalized Cultural Politics. Ed. Russ Castronovo and Dana D. Nelson. Durham: Duke UP, 2002, 175-194. Print.

Frank, Miriam. Out in the Union: A Labor History of Queer America. Philadelphia: Temple UP, 2014. Print.

Gamson, Joshua. The Fabulous Sylvester: The Legend, the Music, the Seventies in San Francisco. New York: Picador, 2005. Print.

Gold, Herbert. “A walk on San Francisco’s gay side.” New York Times. 6 November, 1977. 17. Web. 25 May, 2016.

Gooden, Mario. Dark Space: Architecture, Representation, Black Identity. New York: Columbia UP, 2016. Print.

Graauw, Els De. Making Immigrant Rights Real: Nonprofits and the Politics of Integration in San Francisco. Ithaca: Cornell UP, 2016. Print.

Hanhardt, Christina B. "Butterflies, Whistles, and Fists: Gay Safe Street Patrols and the New Gay Ghetto, 1976-1981." Radical History Review 100 (2008): 61-85. Print.

“The History of the Castro." PBS/KQED (2009). Web. 25 May, 2016.

Howe, Cymene. "Queer Pilgrimage: The San Francisco Homeland and Identity Tourism.” Cultural Anthropology 16: 1 (2001): 35-61. Print.

Johnson, E. Patrick. "Quare Studies, or (Almost) Everything I Know About Queer Studies I Learned from my Grandmother." Text and Performance Quarterly 21:1 (2001): 1-25. Print.

Lenon, Suzanne. "White as Milk: Proposition 8 and the Cultural Politics of Gay Rights." Atlantis 36: 1 (2013): 44-54. Print.

Mennel, Barbara Caroline. Queer Cinema: Schoolgirls, Vampires, and Gay Cowboys. New York: Columbia UP, 2012. Print.

Moore, Patrick. Beyond Shame: Reclaiming the Abandoned History of Radical Gay Sexuality. Boston: Beacon P, 2004. Print.

Ormsbee, J. Todd. The Meaning of Gay: Interaction, Publicity, and Community Among Homosexual Men in 1960s San Francisco. Lanham: Lexington Books, 2010. Print.

Orr, Christopher. “The Mini-review: ‘Milk.”' New Republic (Nov 2008). Web. 25 May, 2016.

Plaster, Joey. "Imagined Conversations and Activist Lineages: Public Histories of Queer Homeless Youth Organizing and the Policing of Public Space in San Francisco's Tenderloin, 1960s to Present." Radical History Review 113 (2012): 99-109. Print.

Ramírez, Horacio. N. Roque. “'That's My Place!': Negotiating Racial, Sexual, and Gender Politics in San Francisco's Gay Latino Alliance, 1975-1983.” Journal of the History of Sexuality 12: 2 (2003): 224258. Print.

Rubin, Gayle S. "Elegy for the Valley of Kings: AIDS and the Leather Community in San Francisco, 1981-1996." In Changing Times: Gay Men and Lesbians Encounter HIV/AIDS Ed. Martin. P. Levine, Peter M. Nardi and John H. Gagnon. Chicago: Chicago UP, 1997, 101-144. Print. 
Shabazz, Rashad. Spatializing Blackness: Architectures of Confinement and Black Masculinity in Chicago. Urbana: Illinois UP, 2015. Print.

Sides, Josh. Erotic City: Sexual Revolutions and the Making of San Francisco. Oxford: Oxford UP, 2009. Print.

Spade, Dean and Craig Willse. “White Knight.” Left Turn. Apr/May (2009): 72-73. Web. 25 May, 2016.

Tookey, Chris. “Milk's dark side stays in the closet.” Daily Mail (Jan 2009). Web. 25 May, 2016.

Vice, Jeff. “Talking Pictures: 'Milk' screenwriter says timing's right for honest portrayal.” Deseret News (Dec 2008). Web. 25 May, 2016.

Walters, Ben. "New-wave queer cinema: ‘Gay experience in all its complexity'.” The Guardian (Oct 2012). Web. 25 May, 2016

White, Armond. "Milk that dead horse, cowboy." New York Press (Nov 2008). Web. 25 May, 2016.

\section{NOTES}

1. The quote is presented here exactly as it's written in Black's screenplay, with ellipses and punctuation retained to emphasize its intended poetic tenor.

2. The Castro in the 1970s as summarized by PBS in their article "The History of the Castro": "In spite of the commonality of sexual orientation, the Castro was not always a harmonious neighborhood. The Castro, as in the greater male-dominated society, was a majority of white gay males who could afford to live and work there. There was an obvious void of women as well as people of color in this community. As a newly arrived black gay male observed: 'Well, I guess this is the gay neighborhood. But it sure is a vanilla gay neighborhood. There's nobody here who looks like me."”

3. In a study of Bay Area publications from within and outside the gay community during the 1960s and 1970s, Ormsbee writes: "The dominant construction of gay as white lies in the dearth of representations of men of color in any of the publications." Ormsbee goes on to further note how, despite there being numerous examples of articles about gay men of color from publications in Honolulu and Chicago, "nothing comparable by gay men of color in the Bay Area was produced during this period" (149).

4. Armond White points to Stonewall (Nigel Finch, 1995) as a film that "risked ignominy by concentrating on gay lib's [sic] actual ethnic component"; Spade and Willse mention Screaming Queens: The Riot at Compton's Cafeteria (Victor Silverman and Susan Stryker, 2005), which is about "the 1966 battle of trans [sic] people against the police in San Francisco's Tenderloin" as "valuable evidence" for a counter history of the gay movement (72); Suzanne Lenon makes the most sustained claim for Milk as "a contemporary site where gay is made white," though the bulk of Lenon's discussion examines the film's overlap with the Proposition 8 vote in 2008 and the film's unflattering depiction of a few non-white characters, primarily Jack Lira (Diego Luna), as Harvey's erratic, suicidal lover. (45).

5. In Black's screenplay, Harvey calls Jack "Taco Bell," instead of "taco."

6. A collection of Milk's political viewpoints entitled An Archive of Hope: Harvey Milk's Speeches and Writings, which was published in 2013 by the University of California Press, helps to demonstrate this; a 1973 letter to the Mayor of San Francisco lamenting the corruption of several groups, including The San Francisco Black Leadership Forum and the Chinese-American Citizens Alliance; in a 1974 column for Vector, Milk likens the tactics used by Dr. Martin Luther King Jr. in the fight for black civil rights to those needed in the struggle for gay rights; in a 1977 speech, perhaps 
Milk's most famous, remembered as the "You've Got to Have Hope" speech, Milk emphasized the city's ethnic diversity, saying the population of San Francisco is "Latins [sic] and Blacks, Whites and Chinese, young and old, straight-and gay."

7. See Ramírez 2003 and Gamson 2005 for examples of Latino and Black men feeling alienated inside Castro bars, which were largely filled with gay white men.

8. In Black's script, the character is not given any description and simply called "Gay Man."

9. See Jasbir Puar's Terrorist Assemblages: Homonationalism in Queer Times for an extended discussion on this trend.

10. Tom Hanks in Philadelphia, Sean Penn in Milk, and Matthew McConaughey in Dallas Buyers Club each won an Academy Award for their performances, respectively. Heath Ledger and Jake Gyllenhaal were both nominated for Brokeback Mountain, but neither won the prize.

11. In the case of a film like Philadelphia, where the co-lead is played by Denzel Washington, the narrative unfolds so that he, a straight man, learns to respect Hanks's character, a gay man dying from AIDS.

12. Though not directly relevant, Rubin further articulate how the rhetorical usage of "unsafesex" included something like fisting "long after it had been eliminated as a serious candidate for AIDS transmission" (113). The implication is that "unsafe-sex" could easily be appropriated as a term of fear against an unfamiliar sexual practice.

\section{ABSTRACTS}

This article examines San Francisco's historically diverse queer districts in relation to the homonormativity present in Milk (Gus Van Sant, 2008) and Test (Chris Mason Johnson, 2013) as a means to reclaim the city's quare spaces. Milk conceals difference through its spatial depiction of an emerging gay civil rights, where not only "gay" but also a coherent social space for queer people comes to be synonymous with whiteness. Accordingly, the largely gay white male population of the Castro District becomes a monolithic emblem of queer history in the city, and restricts access to the queer histories of the Tenderloin and Mission districts, among others. While it is perhaps unsurprising that Milk, a prestige Hollywood film, engages homonormative depictions of queerness, the fact that Test, an American indie, presents San Francisco in a similar manner demonstrates how pernicious this discourse is and that it persists no matter the industrial formation.

\section{INDEX}

Keywords: Castro District, Gus Van Sant, quare, queer homeland, San Francisco, space

\section{AUTHOR}

\section{CLAYTON DILLARD}

Oklahoma State University 